International

\title{
The Youth Guarantee programme in Europe: Features, implementation and challenges
}



Research Department Working Paper No. 4

\title{
The Youth Guarantee programme in Europe: Features, implementation and challenges
}

Verónica Escudero*and Elva López Mourelo**

\author{
August 2015 \\ International Labour Office
}

\footnotetext{
* International Labour Organization Research Department and Paris School of Economics (EHESS),

e-mail: escudero@ilo.org.

** International Labour Organization Research Department, email: lopezmourelo@ilo.org
} 



\begin{abstract}
The recommendation to establish a Youth Guarantee was adopted by the Council in April 2013 in response to unprecedented levels of youth unemployment, which reached 23.5 per cent in Europe at the end of 2012, rising to more than 50 per cent in some countries. The European Youth Guarantee is a commitment by Member States to ensure that all young people receive a good offer of apprenticeship, training, continued education or employment that is suited to their abilities and experience within four months of becoming unemployed or leaving education. The Youth Guarantee is one of the most innovative labour market policies of recent years, and has received strong social support. Indeed, it arrived at a moment when an urgent and radical response was needed to address the detrimental long-lasting consequences of long-term unemployment, such as permanent future income losses, skills erosion and the increased risk of discouragement and inactivity. The aim of this article is to examine the main features of this programme, with a special focus on the factors that are key to its success, namely: early intervention, identification of the right target groups, good institutional frameworks, high quality programmes and sufficient resources. In particular, we assess the extent to which these factors are embedded into the various implementation plans published by the European countries in question. Our analysis shows that although the majority of implementation plans include the recommended combination of capacity building and employment intermediation measures, as well as the creation of adequate institutional frameworks, countries' allocation of resources for the programmes as reported in their implementation plans is not sufficient to match the recommendations. In fact, this article estimates that the gap accumulated by countries analysed that reported less than what is recommended to achieve the desired objective of reducing youth unemployment, amounts to 7.3 billion euros (PPP).
\end{abstract}

Keywords: Youth Guarantee, unemployment, active labour market policies

JEL codes: J08, J21, J23, J24 


\section{Acknowledgements}

The authors would like to thank JooSung Yoon for excellent research assistance and Steven Tobin, Gianni Rosas and colleagues at the ILO Office for the European Union and the Benelux countries for invaluable comments. The authors are also grateful with Pablo Cornide from DG EMP at the European Commission for valuable observations and suggestions. The opinions expressed in this article and the conclusions drawn are the authors', and do not necessarily represent the ILO or its policies. As such, views expressed throughout the paper should be attributed only to the authors, and not to the ILO, its management or its constituents. 


\section{Contents}

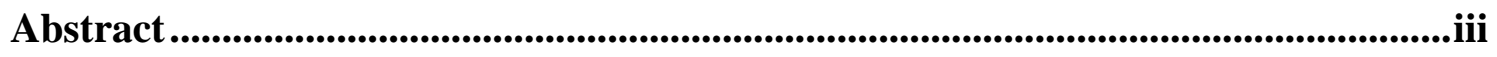

Acknowledgements...............................................................................................................iv

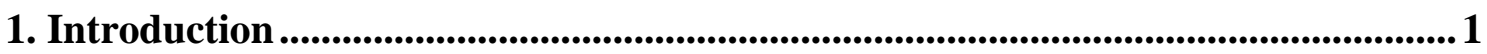

2. The Youth Guarantee: from the Nordic experience to the European initiative ... 2

3. Developing youth guarantee country programmes: components and key

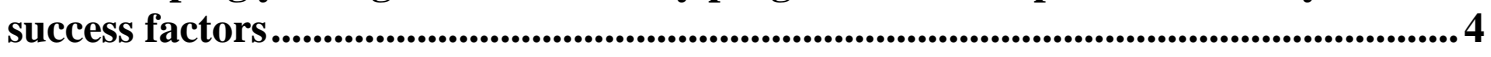

3.1 The impact of youth guarantee programmes: a theoretical analysis ......................................6

3.2. Determining factors in the success of Youth Guarantee programmes .................................. 7

4. Assessment of the Youth Guarantee implementation plans..................................9

4.1. Features of the Youth Guarantee in different European countries........................................10

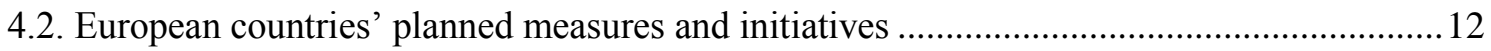

4.3. Compliance with implementation recommendations......................................................... 13

5. Conclusions and policy recommendations ............................................................... 17

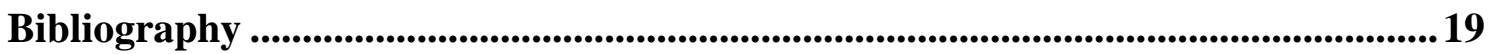

Tables

Table 1 Main features of the Youth Guarantee scheme, by country .........................................11

Table 2 Main features of Youth Guarantee programmes by country.......................................... 14

Table 3 Planned spending on Youth Guarantee schemes by country .......................................16

Figures

Figure 1 Implementation of the European Youth Guarantee timeline ......................................5 


\section{Introduction}

Formally adopted by the Council on 22 April, 2013 (Council, 2013a), following a proposal made by the European Commission (EC) in December 2012 (EC, 2012c), the Youth Guarantee aims to offer a good continued education, apprenticeship, training or employment opportunity to all unemployed young people within four months of their leaving employment or education.

The Youth Guarantee is a response to high levels of youth unemployment. At the end of 2012, the unemployment rate in Europe for people aged 15 to 24 reached 23.5 per cent, and exceeded 50 per cent in some countries - such as Greece (57.9 per cent) and Spain (54.8 per cent). This unsustainable situation threatened to delay economic recovery indefinitely and put the European model of social wellbeing in grave danger. It also brought long-lasting detrimental consequences for young people, such as permanent future income losses, skills erosion and the increased risk of discouragement and inactivity associated with prolonged unemployment spells. As such, it called for a forceful response on the part of the European institutions, which agreed, at the start of 2013, to implement a Europewide youth guarantee programme.

The Youth Guarantee is one of the most innovative labour market policies of the last few decades and has received strong support from all stakeholders, including governments, social partners and civil society. Successfully rolled out in Scandinavian countries, youth guarantees are not simply adjustments to active labour market policies (ALMP), but rather their proper implementation often requires the reform of vocational training systems, education systems and public employment services (PES). However, the fiscal price tag - which is estimated later in this paper at approximately 45 billion euros (PPP) for the EU-28 ${ }^{1}$ - should be viewed as an investment, given the significant reduction that it will produce, if effective, in the costs associated with youth unemployment.

In this context, the aim of this article is to examine the principal features of the European Youth Guarantee programme, with a particular focus on the key factors to its success and their presence in various European countries' implementation processes. Section 2 provides a definition of a youth guarantee, and describes the multiple steps and actions taken to establish the Youth Guarantee at the European level. Section 3 outlines the main actions and interventions envisaged within the framework of the Youth Guarantee, as well as its expected effects on youth unemployment based on economic theory. In addition, this section examines the factors that are critical to the success of national Youth Guarantee programmes. Section 4 evaluates the current state of implementation of the Youth Guarantee in each of the European countries. This section highlights resources reported in the implementations plans, actions completed and European guidelines enacted. Finally, Section 5 presents the conclusions.

\footnotetext{
1 Previous analyses of the ILO estimated its cost at approximately 21 billion euros per year for Eurozone countries (ILO, 2012), based on the Swedish example. As in that case, the estimation presented in this paper is based on the costs of the Swedish programme (6,000 euros per participant in 2010 plus 600 euros per participant for administrative costs). There are three small modifications with regards to the first estimation: 1) costs were adapted to the whole EU-28 (as the estimated cost of 21 billion euros per year corresponds only to Eurozone countries); 2) costs have been adjusted by PPP to take into account country-specific circumstances; and 3) costs have been multiplied by the number of young people not in employment, education or training in 2014 .
} 


\section{The Youth Guarantee: from the Nordic experience to the European initiative}

The idea of a youth guarantee emerged in the 1980s and 1990s in the Nordic countries. This is not surprising since these countries have long been pioneers in the implementation of labour market policies aimed at activation. Sweden, for example, introduced the first youth guarantee in 1984, Norway established a similar programme in 1993, and Denmark and Finland implemented their first youth guarantees in 1996 (Mascherini, 2012; ILO, 2013). Although these pioneering experiments differed in several respects, they had some common features. First of all, they all shared the primary goal of reducing the time spam that young people remained unemployed or inactive. To achieve this, these early youth guarantee programmes sought, first, to prepare customized analyses of the needs of unemployed young people; and, second, to guarantee them an offer of employment, or academic or vocational training opportunity. The second element that they had in common was the crucial role played by PES, which were fundamental to the provision of such a customized approach (Mascherini, 2012). While these first youth guarantees have been modified by various reforms over the last few decades, they effectively reduced youth unemployment even during the crisis of the 1990s, which put them to the test very soon after their creation (ILO, 2012).

The institutions of the European Union took the first steps to establish a European youth guarantee even before the 2008 economic and financial crisis. In 2005, in the context of the preparation of the employment policy guidelines of Member States for the period 2005-2008, the Council agreed that policies should guarantee that "every unemployed young person is offered a new start before reaching 6 months of unemployment". ${ }^{2}$ Subsequently, in 2008, and again in the context of these guidelines but for the period 2008-2010, the Council decided to shorten the timeframe and to offer this guarantee within no more than four months to young people who have left $\operatorname{school}^{3}$ (EC, 2012c).

In 2010, two years after the start of the crisis, the youth unemployment rate in the European Union, at above 20 per cent, had reached an unprecedented high. However, only a few countries - such as Austria that established a youth guarantee programme, Ausbildungsgarantie, in 2008 - had programmes in place to address this challenge since a scheme of this kind did not yet exist at the European level. For this reason, throughout 2010 the number of institutional efforts was multiplied and there were a number of calls by the Parliament, the Commission and the European Youth Forum for the establishment of a European youth guarantee. In September 2010 the Commission launched the "Youth on the Move" initiative, a package of measures designed to reduce youth unemployment. In this Communication, the Commission made a special appeal to Member States to ensure that all unemployed young people would be offered an opportunity to work or to attend training within four months of finishing their studies, thus proposing the concept underlying the Youth Guarantee (EC, 2010). Such appeals were repeated throughout 2011 - particularly by the European Council, the European Parliament and the European Youth Forum - although, in practice, they did not lead to the desired result (EC, 2012d).

However, in 2012 a turning point was reached and more concrete steps were taken towards the establishment of a European youth guarantee. In April 2012, the EC launched an employment package in its Communication entitled "Towards a job-rich recovery". In this employment package, the Commission asked Member States, social partners and other stakeholders to take action to address

\footnotetext{
2 Decision 2005/600/EC of 12 July 2005, OJ L 205, 6.8.2005, p. 21.

${ }^{3}$ Decision 2008/618/EC of 15 July 2008, OJ L 198, 26.7.2008, p. 47.
} 
labour market challenges, particularly those related to youth unemployment. In this context, the Commission insisted on the need for an EU-wide youth guarantee and put forward a proposal for a Council Recommendation to be issued at the end of the year (EC, 2012a).

One month later, in May 2012, the European Parliament insisted on the role of a youth guarantee programme, emphasizing that it would have to be legally enforceable if the problem of youth unemployment in the EU was to be resolved (EC, 2012d). In the same spirit, in its conclusions of 29 June 2012 the European Council highlighted the importance of measures aimed at young people, and affirmed that such measures could receive financial support from the European Social Fund, and that Member States could finance employment subsidies through this Fund.

Finally, in December 2012, the European Commission launched a youth employment package that included a proposal for a Council Recommendation on the establishment of a youth guarantee (EC, 2012c). This proposal set out the principal elements of the Youth Guarantee and articulated six pillars that should underlie its establishment: i) interaction with all stakeholders; ii) early intervention and activation; iii) support for labour market integration; iv) use of European Structural Funds; v) monitoring and evaluation; and vi) early intervention. Furthermore, the proposal specified the mechanisms that the Commission would use to support the establishment of the Youth Guarantee in Member States, namely: a) financial support; b) sharing of good practices; c) monitoring of measures adopted; and d) support for dissemination and awareness-raising activities (EC, 2012c). Then, in April 2013, the Council adopted the proposal as a Recommendation to Member States (Council, 2013a). Importantly, the establishment of the European Youth Guarantee has had the on-going support of the social partners, who also played an active role throughout the entire negotiation process (Bussi and Geyer, 2013). ${ }^{4}$

In addition, throughout 2013, there were movements to provide financing for the Youth Guarantee programme. In February 2013, the European Council agreed to create the Youth Employment Initiative (YEI) with an endowment of 6,000 million euros to support the Youth Guarantee's implementation, intended mainly for regions where levels of unemployment had been higher than 25 per cent in 2012. In June of the same year, the European Council agreed that the funds for the implementation of the Youth Guarantee would be paid out over the course of the period 2014-2016. Furthermore, the European Council urged Member States to present their plans for the implementation of the Youth Guarantee before the end of 2013, with a view to enacting them in 2014 (European Council, 2013b).

Today, the European Youth Guarantee is a commitment by Member States to guarantee that all young people under the age of $25^{5}$ receive, within four months of becoming unemployed or leaving formal education, a good quality offer of work to match their skills and experience; or the chance to continue their studies or undertake an apprenticeship or professional traineeship (Council, 2013a). The Youth Guarantee programme comprises measures to increase young people's employability (e.g. professional training programmes, apprenticeships and initiatives to reduce early school leaving), as

\footnotetext{
${ }^{4}$ A series of discussions between governments and social partners took place between April and October 2012, on the implementation of the Youth Guarantee and the factors that would be vital to its success.

5 The starting age of the Youth Guarantee is country specific and depends on the age at completion of compulsory schooling. In Austria, for example, initiatives to ensure early intervention and activation start already on youth in the last two years of compulsory schooling (i.e. compulsory schooling ends at 15) through activities related to youth coaching.
} 
well as measures aimed to increase the demand for young workers - including, for example, subsidies for hiring young people and support to set up internship programmes.

Based on the overall objective and the measures, the Youth Guarantee scheme has two atypical characteristics that distinguish it from ALMPs. The first one is the "guarantee" concept - i.e. States' commitment to providing unemployed young people with a work or training opportunity. Indeed, under this programme, States and their institutions are committed to mobilize all the resources at their disposal to ensure that no unemployed young person is left behind (Bussi and Geyer, 2013). The second distinctive feature is the establishment of a maximum period of four months from when a young person becomes unemployed or leaves education; other ALMPs generally do not include such timeframes (Besamusca et al., 2012; Bussi and Geyer, 2013).

The Youth Guarantee programme takes as its starting point the fact that young people are a diverse group; it thus emphasizes the need to tailor all measures to each individual young person in search of employment. Therefore, the implementation of this scheme often necessitates the reform of professional training systems, education systems and PES, to enable them to offer customized services that guarantee that all young people are offered a suitable employment or training opportunity within a maximum period of four months. The next section details the main features of this programme, with a special focus on the factors that are key to its success.

\section{Developing youth guarantee country programmes: components and key success factors}

Youth Guarantee national programmes include various measures that aim to offer education, targeted training or employment opportunities to young people. Although these national schemes are based upon the European Youth Guarantee policy framework and must meet certain criteria, their design and implementation varies widely from country to country. However, despite their national specificities, all the programmes entail three kinds of measures: i) education and training for employment, including the provision of professional guidance and help for early school leavers to return to education; ii) employment intermediation services, such as job-search assistance and personalized follow-up of career plans; and iii) ALMPs affecting labour demand, such as hiring subsidies, public work programmes (for example, in community services) and start-up incentives. ${ }^{6}$

Another common feature of many of these Youth Guarantee programmes is that they are run by PES, which are the entities responsible for offering work or education opportunities to candidates who meet eligibility criteria. Efficiency of PES is therefore central to ensuring Youth Guarantee programmes' effectiveness. In fact, often, the management of the services offered by Youth Guarantees is given over to PES at the regional or municipal levels. This being the case, implementation strategies vary according to local contexts.

Overall, the main objective of these elements of youth guarantees is to increase the employability of young people who are not in education, employment or training (NEET). A number of studies have analysed the ways in which measures to increase employability impact employment outcomes, particularly in the context of the OECD countries (Bellmann and Jackman, 1996b; Caliendo and Künn, 2014; Card et al., 2010, among others). The next section describes the effects that each of the interventions comprising the Youth Guarantee is expected to have according to economic theory.

\footnotetext{
${ }^{6}$ These three broad categories are disaggregated further into six categories in section 4.2.
} 


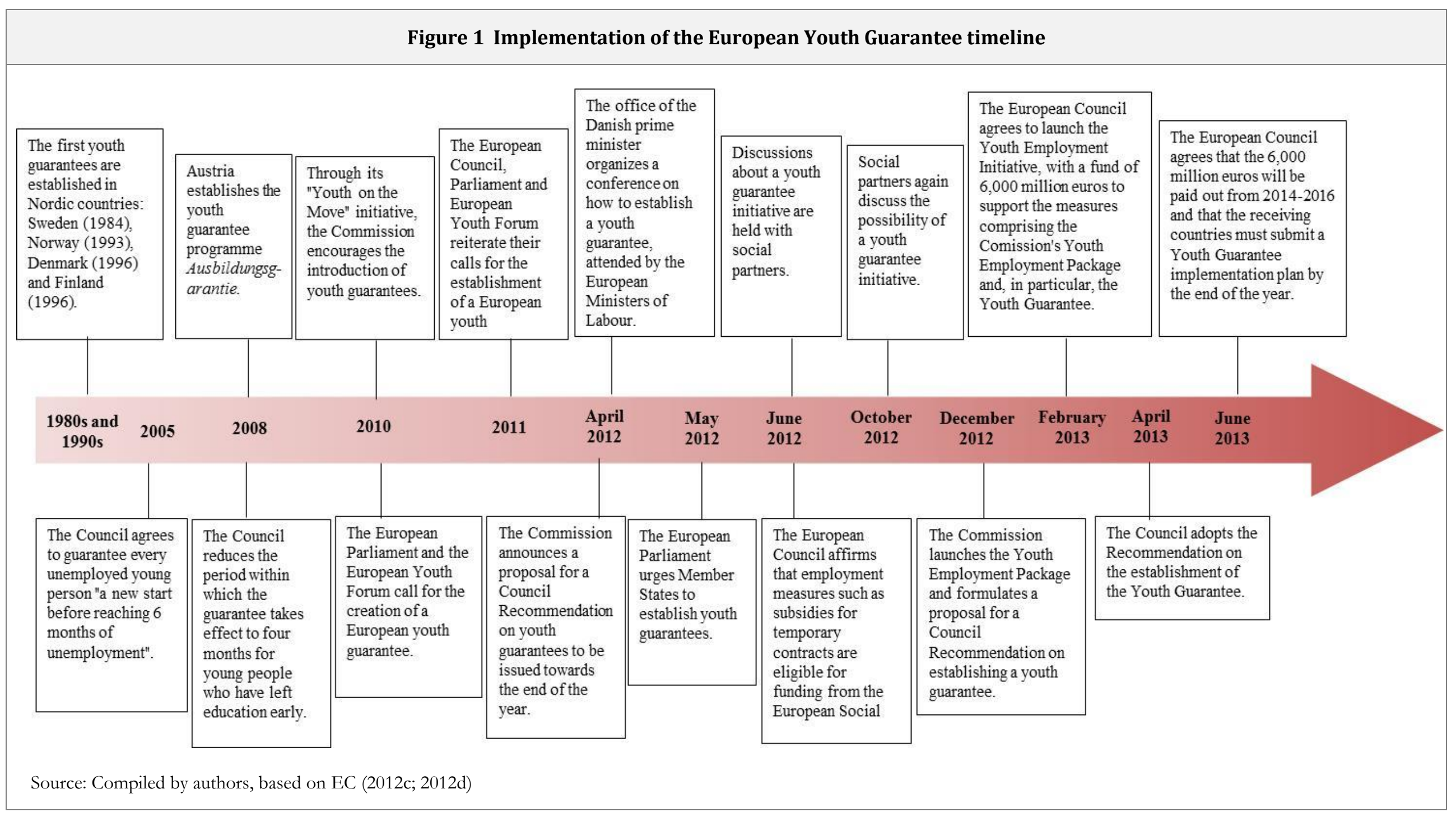




\subsection{The impact of youth guarantee programmes: a theoretical analysis}

According to economic theory ALMPs are justified by their capacity to reduce imbalances and counteract rigidities and distortions in the labour market (Escudero, 2015). Given that governments cannot fight unemployment in a sustainable way simply by increasing aggregate demand (Bellmann and Jackman, 1996a), ALMPs are indispensable mechanisms to: i) reduce imbalances between labour demand and supply; ii) boost workforce productivity; and iii) keep the long-term unemployed and other vulnerable groups connected to the labour market (Layard and Nickell, 1986; Layard et al., 2009). Assuming youth guarantee programmes can obey the same principles of economic theory that other ALMPs do, it would be reasonable to believe that their effect on youth labour market outcomes would be via the main transmission mechanisms related to each of their different areas for action.

Firstly, placement services and job-search assistance (which are components of the Youth Guarantee), are expected to raise the effectiveness of job search (Schmid et al., 2001; Bellmann and Jackman, 1996b; OECD, 1993), which could in turn lead to an increase in the number of vacancies and, correspondingly, labour demand, since it becomes cheaper to create new positions (Pissarides, 1990; Calmfors and Lang, 1995; OECD, 1993). On the other hand, some economists predict that placement services can also lead to a reduced job-search, because government assistance can mitigate the fear of unemployment (Bellman and Jackman, 1996a; Calmfors and Skedinger, 1995).

Furthermore, the training component of youth guarantee programmes is expected to have a significant impact on youth unemployment, although its impact on overall unemployment may be limited (Schmid, 1996). This is because measures designed to build skills have a significant effect on the structure of unemployment by reducing the vulnerability of the most at-risk groups in the labour market, such as young people. Such measures may reallocate employment opportunities, and thus can be said to have a redistributive effect (Escudero, 2015). However, they can also have a displacement effect if beneficiary groups pushes other groups out of the labour market, a lock-in effect if the recipients of training reduce their search intensity while participate in a course (Bellmann and Jackman 1996b) or a deadweight effect if we assume that the jobs found by the targeted youth could have occurred even in the absence of a programme (Calmfors and Skedinger, 1995).

In addition, there may be a number of effects related to the fact that youth guarantee programmes specifically target vulnerable groups. Given that these programmes' main objective is to increase the youth's employability and align their skills to the demand for labour, a reduction in reservation wages is expected as a result of the increased competition for vacancies, ${ }^{7}$ which, in turn, could stimulate labour demand and facilitate employment. However, a reduction in reservation wages could also open the door to more permanent wage moderation in the absence of measures to boost employability, such as training; or if employment options are limited and the number of vulnerable people in the market for jobs is high (Clasen and Clegg, 2006). It is important to note, that the expected effect of youth guarantees on reservation wages would depend on the type of action. Training, in comparison, could raise reservation wages in the long term thanks to an increase in productivity and its associated technological progress.

Lastly, measures designed to increase demand for young workers (e.g. public employment and hiring subsidies) increase levels of employment directly, but also through a multiplier effect; this is

\footnotetext{
${ }^{7}$ In fact, this type of programme is expected to maximize the competition effect, as all the beneficiaries have similar employment profiles (Layard et al., 2009).
} 
particularly true of measures to promote entrepreneurship (EC, 2003). However, these measures can also have the displacement and substitution effect mentioned earlier (OECD, 1993; Calmfors and Skedinger, 1995).

It is worth noting that the fact that youth guarantee programmes are implemented as "guarantees" (one of the unusual characteristics that distinguishes them from other ALMPs) evokes the concept of rights-based programmes. The repercussions of this kind of programme can be different to those associated with programmes based on the utilitarian view that frames the traditional public policy debate. First and foremost, the success of labour-rights programmes or guarantees depends directly on the capacity of labour demand to fulfil the commitments made (Ravallion, 1991). Assuming that it does, rights-based programmes should have a positive impact on employment - as well as on reservation wages - by increasing the bargaining power of targeted workers (Drèze and Sen, 1991; Dev, 1995). On the other hand, if the increase in labour demand is not commensurate to the increase in the number of young people whom youth guarantees prepare to enter the labour market, the effect will be an increase in competition for the existing vacancies, which, as mentioned earlier, would lead to a reduction in reservation wages (Basu et al., 2009). The dominance of one effect or the other will depend, at least partly, on whether governments prioritize distribution over effectiveness in their programme implemention (Basu et al., 2009). A widely implemented programme will tend to enhance competition and reduce reservation wages, while a more targeted programme will provide greater benefits, but only to a specific group.

Which of the effects described in this section will occur, and their magnitude depends on how specific programmes are designed, how they are implemented, the situation of the target groups and the conditions and institutional frameworks of the labour markets in which youth guarantees are implemented. For example, during crises, characterized by high levels of unemployment and low numbers of vacancies, a maximum level of aggregate employment should be assumed, which implies a reduced effectiveness of youth guarantee programmes (Escudero, 2015). Moreover, generally speaking, the weaker the labour market participation of the target group, the lower the impact programmes will have on their employment prospects (Layard et al., 2009). However, economic literature provides ample evidence of the significant effect that the employment conditions of a young person's first job have on his or her ability to find stable, and good quality work in the long term. ${ }^{8}$ It thus appears clear that, for young people, inaction would wreak considerably worse damage than any of the possible undesirable effects associated with ALMPs in general, and youth guarantee programmes in particular. In addition, the negative effects associated with different components of youth guarantees can be mitigated by various factors that can contribute to the success of this kind of programme, as discussed in the next section.

\subsection{Determining factors in the success of Youth Guarantee programmes}

Due to their recent implementation, the impact of Youth Guarantee programmes in Europe has yet to be systematically evaluated. This notwithstanding, the impact evaluations that were done in the countries that pioneered the enactment of youth guarantees show that these measures have had some success in facilitating young people's transition into the labour market (ILO, 2012). The best outcomes, however, come from programmes that include a full range of different measures, as the proposal for the current Youth Guarantee programme does. Successful youth programmes include

${ }^{8}$ See, for instance, Liu et al. (2012). 
those implemented in Norway and England, ${ }^{9}$ which have had excellent results in terms of employment and activation, in both the short and the long terms (Hardoy et al., 2006; Blundell et al., 2004; De Giorgi, 2005). Moreover, data from countries such as Sweden indicate that youth guarantee plans are an efficient way to address youth labour market challenges if they are designed and implemented properly, as they can produce significant effects at a relative modest cost (ILO, 2012).

Many of the main elements of youth guarantee programmes, as these are conceived of today, have been studied in detail, providing insight into their likely outcomes. A number of studies show, for example, that job-search assistance and a personalized follow-up of career plans have positive effects on employment (Dolton and O'Neill, 1996; van den Berg and van der Klaauw, 2006; and Micklewright and Nagy, 2010). Similarly, conditioning benefits to job-search components promotes activation and increases employment rates (Graverson and van Ours, 2008; van den Berg et al., 2009). Lastly, education and professional training are among the most effective measures, especially in the medium to long term, which is when the yields of investment in human capital tend to maximize (Card et al., 2010).

Although further work is needed to gain a deeper understanding of the specific effects of youth guarantee programmes, it is possible to highlight certain prerequisites for their successful functioning (ILO, 2013; ILO, 2014):

- Firstly, intervention must be implemented early. Empirical evidence shows that youth guarantees should be implemented during the first months of unemployment, because prolonged unemployment spells weaken the effectiveness of activation measures. This is true, first, due to skills erosion, which becomes more pronounced the longer the period out of employment. Second, longer unemployment spells increase the risk of abandoning the job search, which makes a transition to inactivity more likely. Importantly, the need for youth guarantees to be implemented in a timely manner has been widely recognized, as is demonstrated by the establishment of a maximum period of four months from the time when a young person becomes unemployed or leaves education within which this guarantee must take effect.

- Secondly, eligibility criteria must be clear and make it possible to identify specific sub-groups within the target group. For instance, to achieve the aforementioned objective it is necessary to identify the most vulnerable youth, and to do so quickly, immediately after their period of unemployment has begun. Once the different target groups have been identified, a package of measures must be developed in line with the specific needs of each group. As such, the measures designed to help a young person who has just left education and has no work experience should not be the same as the support for another young person who has already had a job. In the same line, training and education measures should be tailored to match young people's skill levels.

- Thirdly, the creation of appropriate institutional frameworks is a prerequisite for programmes' successful implementation. In this regard, it is important to highlight the fundamental role played by PES in the implementation of youth guarantee programmes. The success of these programmes will depend on whether PES are properly staffed (in terms of both numbers and competencies) to offer customized support to different groups; and on whether they are well resourced to effectively manage the range of services offered under youth guarantee programmes. Similarly, social dialogue, as well as the participation of all social partners in the design and

\footnotetext{
9 The New Deal programme for young people in England is very similar to the Nordic guarantees.
} 
implementation of the measures, is fundamental. Indeed, one of the success factors of these programmes is their ability to forge cooperative agreements with employers' organizations, trade unions, schools and training centres and non-governmental organizations.

- Fourthly, a useful combination of formal education and training is needed, and these elements must be of the highest quality if they are to enable young people to fully participate in the labour market. In this context, evidence shows that specific skills - particularly when they match labour market's demand - are as important as general skills, and that only through a combination of these two kinds of training can young people be prepared to meet the labour market's requirements. Furthermore, this combination of education and training can be complemented by policies that help young people to gain work experience (e.g. such as apprenticeships) in order to achieve a long-term integration into the labour market.

- And, fifthly, ensuring sufficient resources is indispensable to the effective operation of these programmes. This requires accurate projection of the funds required, and also ensuring that the budget is flexible enough to enable programmes to effectively respond to economic cycles. Finland's experience of the recent economic crisis demonstrated the importance of this flexibility, when the rapid increase in the demand for measures to support the unemployed youth proved a challenge for the Finnish PES (ILO, 2013). In line with this, the experience of Sweden proved that youth guarantees can yield positive impacts at a relative modest cost. In 2010 (latest available figures), the estimated cost per participant of the Swedish youth guarantee plan was approximately 6,000 euros plus administrative costs (approximately 600 euros per participant), an investment that had a 46 per cent success rate (ILO, 2012).

\section{Assessment of the Youth Guarantee implementation plans}

As described in Section 2, in June 2013 the European Council urged Member States - that would benefit from YEI - to present their Youth Guarantee implementation plans by the end of 2013, with a view to putting these into action in 2014 (European Council, 2013b). All countries that would benefit from YEI complied and, therefore, presented their Youth Guarantee implementation plans by 31 December 2013. The rest of Member States were encouraged to adopt similar plans in 2014. As such, Austria, Denmark, Estonia, Finland, Germany, Malta, the Netherlands and the United Kingdom launched their projects over the course of the first half of 2014. ${ }^{10}$ By May 2014, all the European countries had presented their Youth Guarantee implementation plans. Over the course of 2014, some countries - including Belgium, Croatia, Hungary and Sweden - even submitted updated versions of the plans they had presented at the end of 2013.

This section examines published European countries' implementation plans in detail. It presents a comparative analysis with regard to the main features of the Youth Guarantee, the implementation of the various measures and whether the different plans include the factors that have been identified as key to the success of this type of programme. It is important to keep in mind that Youth Guarantee implementation plans are preliminary documents and that the actual implementation of the national

\footnotetext{
10 Some of these countries, including Austria and Denmark, already had youth guarantees, which they remodelled and adapted to comply with the European Commission's Recommendation. Thus, the implementation plans they presented contained already the main features of a youth guarantee according to the European guidelines.
} 
youth guarantees will have most probably modified a number of aspects, even including additional programmes and increased resource allocations.

\subsection{Features of the Youth Guarantee in different European countries}

The submission of implementation plans was the central requirement for European countries to benefit from the 6,000 million euros that the European Council had mobilized through the Youth Employment Initiative (YEI) to fund the establishment of the different Youth Guarantees. However, these funds were earmarked for those regions which had had a youth unemployment rate higher than 25 per cent in 2012. Moreover, an additional requirement was set where funds would be granted provided that countries match this grant with a contribution of at least the same amount from their European Social Fund allocation. ${ }^{11}$ Out of the 21 countries for which information on Youth Guarantee implementation plans is available, 14 were considered eligible for YEI funding (Table 1). By contrast, Austria, Denmark, Estonia, Finland, Germany, Luxembourg and the Netherlands were not considered eligible because there were no regions within their borders where youth unemployment had been higher than 25 per cent in 2012. ${ }^{12}$ In terms of the distribution of YEI funds, Spain for example received the largest allocation (943.5 million euros), followed by Italy (567.5 million euros) and France (310.2 million euros); whilst the smallest allocation went to the Czech Republic (13.6 million euros). ${ }^{13}$

According to the Council Recommendation of April 2013, through the Youth Guarantee countries must commit to ensuring that all young people under the age of 25 receive, within four months of becoming unemployed or leaving education, good continued education, apprenticeship, training or employment opportunity. While most countries have followed the European Commission's recommendation and targeted under-25s, there are some exceptions, such as Croatia, the Czech Republic and Portugal, where Youth Guarantees are aimed at people under 30 years of age. In Spain the target group includes youth under 25, or 30 for people with a disability level equal to or greater than 33 per cent (Government of Spain, 2013b). The vast majority of countries have followed the European recommendation with regard to the maximum period within which young people must be offered an employment or training opportunity (fixed at four months). However, some Nordic countries (Denmark, Finland and Sweden), as well as Austria and Germany, have opted for a shorter period, of three months.

Lastly, as regards Youth Guarantee eligibility criteria, most countries require young people to be unemployed and registered with PES. Finland, Portugal, Romania and Spain are exceptions, requiring young people only to be not in employment, education or training.

\footnotetext{
11 Indeed, governments advance projects costs with national budget and the expenditure incurred is then reimbursed from EU funds. However, in order to help countries with the initial implementation, a percentage of EU funds (i.e. the pre-financing rate) is frontloaded. This rate was set at 1 per cent of the total allocation initially (or 1.5 per cent for countries under financial assistance). In February 2015, this original pre-financing rate was modified and fixed at 30 per cent of the total allocation due to the lack of available funding reported by some Members States (EC, 2015).

12 Despite not meeting the requirements for access to funding, these countries have also implemented Youth Guarantee programmes.

${ }^{13}$ It is worth noting that funding allocation was based on the size of the target population in each country.
} 
Table 1 Main features of the Youth Guarantee scheme, by country

\begin{tabular}{|c|c|c|c|c|c|c|}
\hline & $\begin{array}{c}\text { Date of } \\
\text { presentation }\end{array}$ & Target group & Eligibility criteria & $\begin{array}{l}\text { Maximum } \\
\text { period }\end{array}$ & $\begin{array}{l}\text { Eligible } \\
\text { for YEI }\end{array}$ & $\begin{array}{l}\text { Allocation } \\
\text { (millions } \\
\text { of euros) }\end{array}$ \\
\hline Austria & March 2014 & Under-25s & $\begin{array}{l}\text { - Unemployed -and- } \\
\text { - Registered with PES }\end{array}$ & 3 months & $x$ & \\
\hline Belgium & April 2014 & Under-25s & $\begin{array}{l}\text { - Unemployed -and- } \\
\text { - Registered with PES }\end{array}$ & 4 months & $\checkmark$ & 42.4 \\
\hline Croatia & April 2014 & Under-30s & - Unemployed & 4 months & $\checkmark$ & 66.2 \\
\hline $\begin{array}{l}\text { Czech } \\
\text { Republic }\end{array}$ & December 2013 & Under-30s & $\begin{array}{l}\text { - Unemployed -and- } \\
\text { - Actively looking for work }\end{array}$ & 4 months & $\checkmark$ & 13.6 \\
\hline Denmark & April 2014 & Under-25s & $\begin{array}{l}\text { - Unemployed -and- } \\
\text { - Registered with PES }\end{array}$ & 3 months & $x$ & \\
\hline Estonia & April 2014 & Under-25s & - Unemployed & 4 months & $x$ & \\
\hline Finland & May 2014 & $\begin{array}{l}\text { Under- } 25 \text { s and } \\
\text { recent graduates } \\
\text { under } 30\end{array}$ & - NEETs & 3 months & $x$ & \\
\hline France & December 2013 & Under-25s & $\begin{array}{l}\text { - Unemployed -and- } \\
\text { - Registered with PES }\end{array}$ & 4 months & $\checkmark$ & 310.2 \\
\hline Germany & April 2014 & Under-25s & $\begin{array}{l}\text { - Unemployed -and- } \\
\text { - Registered with PES }\end{array}$ & 3 months & $x$ & \\
\hline Hungary & April 2014 & Under-25s & $\begin{array}{l}\text { - Registered with PES -or- } \\
\text { - NEETs }\end{array}$ & 4 months & $\checkmark$ & 49.8 \\
\hline Ireland & December 2013 & Under-25s & $\begin{array}{l}\text { - Unemployed -and- } \\
\text { - Registered with PES }\end{array}$ & 4 months & $\checkmark$ & 68.1 \\
\hline Italy & December 2013 & Under-25s & $\begin{array}{l}\text { - Unemployed -and- } \\
\text { - Registered with PES }\end{array}$ & 4 months & $\checkmark$ & 567.5 \\
\hline Latvia & April 2014 & Under-25s & $\begin{array}{l}\text { - Unemployed -and- } \\
\text { - Registered with PES }\end{array}$ & 4 months & $\checkmark$ & 29.0 \\
\hline Lithuania & May 2014 & Under-25s & $\begin{array}{l}\text { - Unemployed -and- } \\
\text { - Registered with PES }\end{array}$ & 4 months & $\checkmark$ & 31.8 \\
\hline Luxembourg & May 2014 & Under-25s & - Unemployed & 4 months & $x$ & \\
\hline Netherlands & April 2014 & Under-25s & $\begin{array}{l}\text { - Unemployed -and- } \\
\text { - Registered with PES }\end{array}$ & 4 months & $x$ & \\
\hline Poland & December 2013 & Under-25s & $\begin{array}{l}\text { - Unemployed -and- } \\
\text { - Registered with PES }\end{array}$ & 4 months & $\checkmark$ & 252.4 \\
\hline Portugal & December 2013 & Under-30s & - NEETs & 4 months & $\checkmark$ & 160.8 \\
\hline Romania & December 2013 & Under-25s & - NEETs & 4 months & $\checkmark$ & 106.0 \\
\hline Spain & December 2013 & $\begin{array}{l}\text { Under-25s and } \\
\text { disabled under- } \\
30 \text { s }\end{array}$ & - NEETs & 4 months & $\checkmark$ & 943.5 \\
\hline Sweden & April 2014 & Under-25s & $\begin{array}{l}\text { - Unemployed -and- } \\
\text { - Registered with PES }\end{array}$ & 3 months & $\checkmark$ & 44.2 \\
\hline
\end{tabular}

Note: This table only contains information on the countries that have Youth Guarantee implementation plans available online. For this reason, there is no information on Bulgaria, Cyprus, Greece, Malta, Slovakia, Slovenia or the United Kingdom. The information on Belgium combines all the initiatives included in its four regional plans. Dates of presentation refer to the latest versions of plans submitted.

Source: Compiled by authors, based on the Youth Guarantee implementation plans available online http://ec.europa.eu/social/main.jsp?catId=1161\&langId=en\&intPageId=3347. 


\subsection{European countries' planned measures and initiatives}

An examination of all the European countries' implementation plans reveals a wide variety of measures and initiatives planned within the framework of the Youth Guarantee. Despite this diversity, measures can generally be divided into six categories: i) education and training for employment; ii) measures to reduce school dropout and provide remedial education; iii) employment intermediation services; iv) direct employment creation; v) hiring subsidies; and vi) start-up incentives. This classification is a further division of the three broad categories presented in Section 3.

As Table 2 shows, all European countries incorporate education and training for employment into their implementation plans. The principal goal of this kind of initiative is to improve young people's skills to enable them to better meet labour market demands. For instance, Austria has a Training Guarantee that ensures that all young people who completed compulsory schooling (15 years of age) and are younger than 18 (or 24 if they have any kind of disability) have access to an apprenticeship with a firm. In addition, it has established a training programme for apprentices that provides them support and advice throughout their training. This programme aims to ensure the completion of apprenticeships and to increase success rates. Another interesting measure of this type is the launch of a dual professional training scheme in Spain that combines training with work experience in a company, via a Training and Apprenticeship Contract. These contracts last between one and three years, with 75 per cent of time spent working during the first year and 85 per cent over the next two years, with the remaining time used for training.

Likewise, all European countries' implementation plans include measures to reduce school dropout and provide remedial education. Germany's initiatives, for example, aim to help young people get a secondary school diploma and reduce the risk of them leaving school without any qualifications. To this end, Germany's Youth Guarantee includes, among other things, tutoring sessions to encourage the take up of training programmes; professional preparation programmes; and specific strategies to support the most vulnerable students. Along these same lines, Spain is planning to implement secondchance programmes, designed to encourage young people who left school early to return to education. The evaluation and accreditation of skills gained through work experience or informal training is another Spanish measure designed to help those who left school acquire skills but also qualifications.

The final category of measures that all European countries' implementation plans include is employment intermediation, such as job-search assistance and personalized follow-up of career plans. These measures aim to boost young people's individual efforts and increase the effectiveness of their job-searches, and to facilitate the matching of labour supply to demand. In an effort to improve labour intermediation services, Luxembourg, for example, undertook significant reforms of its PES in 2012, including a thorough review of all operations and the launch of new procedures. Furthermore, it has increased the number of staff in PES offices and provided each office with a person focusing exclusively on the implementation of the Youth Guarantee.

Regarding hiring incentives, almost all the implementation plans include these measures, with the exception of Austria and the Czech Republic. Importantly, these hiring subsides generally take the form of wage subsidies or reductions in hiring costs through social security bonuses. For example, Denmark has introduced a wage subsidy that allows private sector enterprises that hire an unemployed young person to receive compensation for a maximum period of one year (this period is reduced to six months for the public sector). Meanwhile, Sweden has introduced an allowance for hiring young people under 36 years of age that sets the social security contribution for this group at 15.49 per cent, in contrast to the standard rate of 31.42 per cent. 
On the other side of the spectrum, the least commonly found category of measures in the Youth Guarantee implementation plans is direct employment creation. Only Belgium, Croatia, Ireland, Luxembourg and Spain have considered implementing temporary hiring programmes. For instance, Croatia has established a community services public employment programme with a maximum duration of 12 months, targeting young people under the age of 30 who have been unemployed for at least six months. Along these same lines, Spain is considering including in its Youth Guarantee implementation plan Escuela Taller and Casas de Oficios programmes, through which participants undertake useful community projects related to the maintenance of urban spaces or the protection of cultural heritage.

Lastly, the vast majority of European countries include programmes to encourage entrepreneurship in their Youth Guarantee implementation plans. In general, these programmes offer financial support for the establishment of new businesses, as well as the training and advice necessary to increase their survival rate. For example, in its implementation plan, Latvia includes launching a programme to support young entrepreneurs (under 30 years), which includes guidance on their business proposals and a 3,000-euro grant if the PES deems that these proposals merit support. In addition, the programme also includes advice during the first year of an enterprise's operation, and a wage subsidy for the first six months.

Importantly, this section has reviewed all active labour market programmes at the country level planned within the framework of the Youth Guarantee. However, national Youth Guarantee schemes also include other measures such as labour market and education system reforms, adoption of and amendments to laws concerning youth issues, and initiatives aimed to promote poverty reduction and social development. Although a detailed analysis of this last component is beyond the scope of this paper, the last column of Table 2 provides a list by country of these additional actions as included in the implementation plans.

\subsection{Compliance with implementation recommendations}

The first part of this section showed that countries have opted for early intervention in their Youth Guarantee implementation plans, fixing a maximum period of either three or four months for the provision of the Youth Guarantee. Furthermore, this section showed that all European Union countries, albeit in different ways, have launched measures or initiatives designed to support unemployed young people's integration into the labour market. In addition, all the countries have outlined a combination of formal education measures and professional training policies. Likewise, they have all established clear eligibility criteria and created specific measures for the most vulnerable young people. For instance, as described earlier, Croatia has set up a public employment programme for young people who have been unemployed for a long period, while Germany has focussed its efforts on training for its least able students. The objective of this last section is to determine whether Member States have complied with the remaining European Commission recommendations, namely: to develop suitable institutional frameworks and the sufficient allocation of resources. 
Table 2 Main features of Youth Guarantee programmes by country

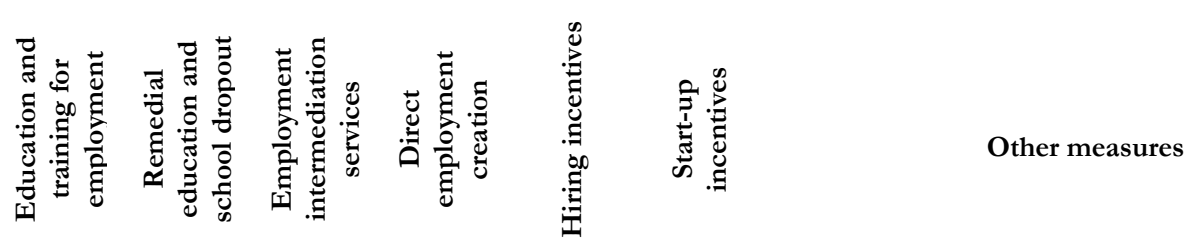

\begin{tabular}{|c|c|c|c|c|c|c|c|}
\hline Austria & $\checkmark$ & $\checkmark$ & $\checkmark$ & & & $\checkmark$ & \\
\hline Belgium & $\checkmark$ & $\checkmark$ & $\checkmark$ & $\checkmark$ & $\checkmark$ & $\checkmark$ & - Financial help for young people on low incomes \\
\hline Croatia & $\checkmark$ & $\checkmark$ & $\checkmark$ & $\checkmark$ & $\checkmark$ & $\checkmark$ & $\begin{array}{l}\text { - Development of a system to identify young NEETs. } \\
\text { - Adoption of a Law on Youth } \\
\text { - Development of a labour market monitoring and } \\
\text { evaluation system }\end{array}$ \\
\hline $\begin{array}{l}\text { Czech } \\
\text { Republic }\end{array}$ & $\checkmark$ & $\checkmark$ & $\checkmark$ & & & & - System for evaluating and predicting necessary skills \\
\hline Denmark & $\checkmark$ & $\checkmark$ & $\checkmark$ & & $\checkmark$ & & $\begin{array}{l}\text { - Encouragement of ethnic minority young people to } \\
\text { pursue secondary and further education }\end{array}$ \\
\hline Estonia & $\checkmark$ & $\checkmark$ & $\checkmark$ & & $\checkmark$ & & \\
\hline Finland & $\checkmark$ & $\checkmark$ & $\checkmark$ & & $\checkmark$ & & - Workshops on developing soft skills \\
\hline France & $\checkmark$ & $\checkmark$ & $\checkmark$ & & $\checkmark$ & $\checkmark$ & \\
\hline Germany & $\checkmark$ & $\checkmark$ & $\checkmark$ & & $\checkmark$ & $\checkmark$ & $\begin{array}{l}\text { - Use of online chats between counsellors and young } \\
\text { people seeking employment intermediation services } \\
\text { - Promotion of regional and international mobility }\end{array}$ \\
\hline Hungary & $\checkmark$ & $\checkmark$ & $\checkmark$ & & $\checkmark$ & $\checkmark$ & $\begin{array}{l}\text { - Amendments to laws concerning professional } \\
\text { training } \\
\text { - Poverty reduction in isolated areas, particularly } \\
\text { among gypsy/Roma populations }\end{array}$ \\
\hline Ireland & $\checkmark$ & $\checkmark$ & $\checkmark$ & $\checkmark$ & $\checkmark$ & $\checkmark$ & - Promotion of part-time employment \\
\hline Italy & $\checkmark$ & $\checkmark$ & $\checkmark$ & & $\checkmark$ & $\checkmark$ & - Promotion of regional and international mobility \\
\hline Latvia & $\checkmark$ & $\checkmark$ & $\checkmark$ & & $\checkmark$ & $\checkmark$ & $\begin{array}{l}\text { - Reform of education systems } \\
\text { - Promotion of regional mobility }\end{array}$ \\
\hline Lithuania & $\checkmark$ & $\checkmark$ & $\checkmark$ & & $\checkmark$ & $\checkmark$ & \\
\hline Luxembourg & $\checkmark$ & $\checkmark$ & $\checkmark$ & $\checkmark$ & $\checkmark$ & $\checkmark$ & $\begin{array}{l}\text { - PES reform } \\
\text { - PES-employer information meetings } \\
\text { - Promotion of international mobility }\end{array}$ \\
\hline Netherlands & $\checkmark$ & $\checkmark$ & $\checkmark$ & & $\checkmark$ & & \\
\hline Poland & $\checkmark$ & $\checkmark$ & $\checkmark$ & & $\checkmark$ & $\checkmark$ & $\begin{array}{l}\text { - Amendment of the Act on Employment Promotion } \\
\text { and Labour Market Institutions } \\
\text { - Promotion of regional mobility }\end{array}$ \\
\hline Portugal & $\checkmark$ & $\checkmark$ & $\checkmark$ & & $\checkmark$ & $\checkmark$ & - Promotion of international mobility \\
\hline Romania & $\checkmark$ & $\checkmark$ & $\checkmark$ & & $\checkmark$ & $\checkmark$ & - PES reform \\
\hline Spain & $\checkmark$ & $\checkmark$ & $\checkmark$ & $\checkmark$ & $\checkmark$ & $\checkmark$ & $\begin{array}{l}\text { - PES reform } \\
\text { - Mobility programmes }\end{array}$ \\
\hline Sweden & $\checkmark$ & $\checkmark$ & $\checkmark$ & & $\checkmark$ & & - Promotion of regional mobility \\
\hline
\end{tabular}

Source: Compiled by authors, based on the Youth Guarantee implementation plans available online http://ec.europa.eu/social/main.jsp?catId=1161\&langId=en\&intPageId=3347. 
As regards the various institutions responsible for the Youth Guarantee's smooth operation, it is important to highlight that in most countries a wide range of different actors are involved. In terms of public administration, the responsible body in most countries is the Ministry of Labour, although Ministries of Education, Social Affairs and Science and Research are also involved. Perhaps least expected is the participation of the Ministries of Defence, in Finland and France, whose role is to organize workshops on citizenship with the aim of reaching young people who are not in education or employment. Moreover, almost all countries' implementation plans outline PES' responsibilities, which is not surprising given the central role PES has in the provision of the different services outlined in the Youth Guarantee. Often, programmes incorporate regional- or municipal-level interventions, meaning that, in implementation plans, bodies that function below the national level are given a key role. Lastly, it should be noted that social partners are heavily involved in implementing the Youth Guarantee in most of the countries analysed. This is not surprising, as the social partners provided their support at every stage of the negotiation process (see Section 2). Not only trade unions and employers' organizations are involved, but in the majority of countries there is also collaboration with youth organizations, education and training centres, universities and research centres.

Furthermore, available information exists as well that allows for an initial assessment of the reported expenses countries foresaw for the launch of the Youth Guarantee in the implementation plans. Table 3 shows the planned spending for the implementation of Youth Guarantee measures (during the first two years) in the 16 countries for which information is available. The first thing that immediately stands out is the significant variation in spending per eligible participant across the different countries. Indeed, Germany, with an allocation of 20,765.3 euros (PPP) per eligible participant, is the country with the highest planned spending, followed by the Hungary $(13,384.8$ euros, PPP) and Austria (11,081.3 euros, PPP). Meanwhile, with an over 10,000-euro-PPP difference per young NEET, countries with the lowest expenditure planned per NEET include Croatia (115.1 euros, PPP) and Belgium (797.4 euros, PPP). This outcome is not unexpected since German PES is well-known to be well resourced. Indeed, in 2011 Germany had 44 PES staff for every 1,000 unemployed people, the highest among EU countries with available information (ILO, 2014).

The second outcome of the analysis of reported expenditure by country emerges from a comparison with what could be considered a recommended spending based on the Swedish example discussed in Section 3. It is important to remember that the interesting feature of the Swedish example lies in its positive effects at a relative modest cost. Based on this case, the estimated costs of a youth guarantee plan for the EU-28 would have been approximately 45,400 million euros (PPP) (or 0.69 per cent of total general government spending) in 2014. This is the total budget that would have been needed to take into account the number of young NEETs in 2014. However, most of the European Youth Guarantee plans are targeted to different groups with varying eligibility criteria (Table 1). As such, a comparison of the recommended spending adapted to the particular eligibility criteria of countries with the amounts reported by countries in their implementation plans reveals that more than 60 per cent of countries have submitted proposed expenditures that are below the recommended threshold. This divergence is greatest in the case of Croatia and Belgium, which point to a spending of 12 and 7 times, respectively, less than what was recommended. Conversely, some countries, including Germany and Hungary, have submitted budgets in their implementation plans that point to a spending of around 3 times the recommended amounts on Youth Guarantee initiatives and measures.

Finally, having assessed how countries have complied with the different recommendations of the European Commission, it is useful to mention how the mechanisms that the Commission set to support the establishment of country-specific Guarantees (discussed in Section 2) have evolved. In particular, the monitoring of measures adopted and sharing of good practices are two aspects that the 
European Commission underlined as central during the implementation of Youth Guarantees. Regarding the first point, early during the implementation of the European Youth Guarantee (between August and September 2013), at the request of the European Parliament, the European Commission launched 18 Youth Guarantee pilot projects in seven member states: Ireland, Italy, Lithuania, Poland, Romania, Spain and the UK. A number of preliminary trends have emerged already from these experiences that are worth mentioning. Overall, pilot schemes seem to have a positive effect in the way employment and school-to-work transition services are delivered. In addition, they have performed well against their objective of delivering short-term relief in areas of high youth unemployment. Regarding the ability to provide an employment or training opportunity within four months, evidence from pilot projects suggests that this goal has been achieved in around 83 to 98 per cent of the youths. Finally, pilot projects performed at a lower cost per participant than other services, although this depended on how efficiently funds were used and varied across countries (EC, 2015). Regarding the second point, the Commission is keen to facilitate the sharing of best practices between

Table 3 Planned spending on Youth Guarantee schemes by country

\begin{tabular}{|c|c|c|c|c|c|}
\hline & $\begin{array}{l}\text { Amounts } \\
\text { reported in } \\
\text { implementation } \\
\text { plans (million of } \\
\text { euros PPP) }\end{array}$ & $\begin{array}{l}\text { Number of } \\
\text { eligible } \\
\text { participants } \\
\text { (thousands) }\end{array}$ & $\begin{array}{l}\text { Amounts } \\
\text { reported per } \\
\text { eligible } \\
\text { participant } \\
\text { (euros PPP) }\end{array}$ & $\begin{array}{c}\text { Estimated } \\
\text { recommended } \\
\text { spending } \\
\text { (million of euros } \\
\text { PPP) }\end{array}$ & $\begin{array}{c}\text { Resources gap } \\
\text { (million of euros } \\
\text { PPP) }\end{array}$ \\
\hline & (A) & (B) & $(\mathrm{A} / \mathrm{B})$ & (C) & $(\mathrm{A}-\mathrm{C})$ \\
\hline Austria & 644.9 & 58.2 & $11,081.3$ & 347.7 & 297.2 \\
\hline Belgium & 73.8 & 92.6 & 797.4 & 551.0 & -477.1 \\
\hline Croatia & 14.6 & 126.8 & 115.1 & 173.1 & -158.5 \\
\hline Czech Republic & 640.7 & 98.6 & $6,498.0$ & $1,026.1$ & -385.4 \\
\hline Denmark & 78.8 & 55.6 & $1,418.0$ & 272.5 & -193.7 \\
\hline Estonia & 16.3 & 8.4 & $1,944.0$ & 74.3 & -58.0 \\
\hline Finland & 184.0 & 64.6 & $2,849.9$ & 342.8 & -158.8 \\
\hline France & $3,841.4$ & 621.2 & $6,183.8$ & $3,736.9$ & 104.4 \\
\hline Germany & $6,800.6$ & 327.5 & $20,765.3$ & $2,075.6$ & $4,725.0$ \\
\hline Hungary & $2,044.2$ & 152.7 & $13,384.8$ & 788.5 & $1,255.7$ \\
\hline Ireland & 474.8 & 46.8 & $10,144.6$ & 277.7 & 197.1 \\
\hline Italy & $1,776.7$ & 692.1 & $2,567.1$ & $4,553.4$ & $-2,776.7$ \\
\hline Latvia & 40.5 & 16.9 & $2,394.8$ & 162.7 & -122.3 \\
\hline Netherlands & 922.2 & 145.9 & $6,320.5$ & 882.0 & 40.1 \\
\hline Poland & $1,736.7$ & 347.4 & $4,999.0$ & $3,965.2$ & $-2,228.5$ \\
\hline Romania & 416.2 & 384.7 & $1,081.8$ & $1,111.8$ & -695.6 \\
\hline
\end{tabular}

Note: Figures illustrate the cost of the implementation of Youth Guarantee measures for the first two years. This table includes only information on the countries that have Youth Guarantee implementation plans available online, and which include data on expected implementation costs. Therefore, there is no information on Bulgaria, Cyprus, Greece, Lithuania, Luxembourg, Malta, Portugal, Slovakia, Slovenia, Spain, Sweden and the United Kingdom. The information on Belgium combines all the initiatives under its four regional plans. Figures for Ireland correspond to 2014 expenditure. Estimated costs have been calculated based on the costs of the Swedish programme, which in 2010 amounted to 6,000 euros per participant. To calculate the total cost, administrative costs have been added, which in the case of Sweden were estimated at 600 euros per participant. These administrative costs represent the resources that would have been necessary for PES to assist all young people not in employment, education or training in 2014. However, in this table rather than NEET, figures illustrate costs based on the number of eligible participants, according to the eligibility criteria shown in Table 1.

Source: Compiled by authors, based on the Youth Guarantee implementation plans available online http://ec.europa.eu/social/main.jsp?catId=1161\&langId=en\&intPageId=3347. 
governments, in particular through the European Employment Strategy Mutual Learning Programme (MLP) ${ }^{14}$ which already has information on the general aspects of the European Youth Guarantee and the country-specific implementation plans. Best practices, however, have not been particularly shared through this tool yet.

\section{Conclusions and policy recommendations}

The launch of the European Youth Guarantee in April 2013 raised great attention among stakeholders in Europe. First, due to its innovative features but also because this measure arrived in a moment when high youth unemployment levels that had persisted in the region since the 2008 crisis, required an urgent response. Member States' commitment to ensuring that young NEETs received a good continued education, apprenticeship, training or employment opportunity within a maximum period of four months seemed an appropriate policy response given the magnitude of the problem. Yet, it needs to be stressed the scheme was not launched as early as it should have. This article analyses the specifics of this guarantee, its importance and possible repercussions. It also assesses, through a review of the implementation plans, whether the different commitments outlined in the scheme have been met in practice.

Due to its recent implementation, an empirical evaluation of the impact of the European Youth Guarantee has not been conducted systematically yet. Importantly, impact evaluations of the youth programmes implemented in the Nordic countries, pioneers in this area, have not consistently revealed positive outcomes. However, it would be wrong to judge the effectiveness of the Youth Guarantee solely on the basis of programmes rolled out in the 1990s, which were significantly different, in terms of their components and methods of implementation, to that which is currently proposed. In fact, as discussed in Section 3, empirical evidence shows that the best outcomes are achieved when programmes incorporate a full range of interventions (e.g. youth programmes in Norway and England) as it is proposed in the current Youth Guarantee programme. Moreover, some of the main elements of today's Youth Guarantee programmes have been studied in much greater detail, and have shown short- and long-term positive effects on both employment and activation.

With this in mind, data from countries where these measures have yielded positive results suggest that youth guarantee plans are an effective way of responding to youth unemployment provided they are designed and implemented properly, as they can produce significant change at modest cost. This article has identified five elements that are fundamental to the effective functioning of these programmes, namely: early intervention, identification of the right target groups, good institutional frameworks, high quality programmes and sufficient resources.

Thus, there is no doubt that the implementation of the European Youth Guarantee scheme is a welcome initiative, especially in view of the scale of the actions planed. In fact, although the implementation process is still underway, analysis shows that the majority of European countries have already taken important steps towards the establishment of the Youth Guarantee. By May 2014, for instance, all the European countries had presented their implementation plans. Although, examination of these plans reveals a wide variety of measures planned within the framework of the Youth Guarantee, all countries' implementation plans include most of the main elements recommended. This

\footnotetext{
${ }_{14}$ The MLP is a tool created for the open method of coordination in the field of EU employment policy that supports, coordinates, encourages and disseminates mutual learning between EU Member States (Art. 149 of the Treaty on the Functioning of the European Union - EC, 2012b).
} 
is, programmes focussed on education and training for employment; initiatives to reduce school dropout and provide remedial education; and employment intermediation services. Furthermore, all the countries have established clear eligibility criteria and developed specific measures targeting the most vulnerable young people.

Moreover, most countries have likewise focussed on creating appropriate institutional frameworks, a key factor in the success of youth guarantees. In this context, a number of States have incorporated plans for the modernization of their PES into their implementation plans, in order to ensure that the necessary requirements for the establishment of an effective Youth Guarantee can be met. Social dialogue and the participation of all the social partners in the design, implementation and execution of measures play an essential role. It is thus encouraging that, in the majority of countries, cooperation agreements have been forged with employers' organizations, trade unions, schools and training centres, and non-governmental organizations.

It is clear that countries have made significant economic efforts to activate the Youth Guarantee. In fact, some countries have planned a significant per capita expenditure that is even notably higher than what is recommended in this article; Ireland is a case in point. However, while every country has ensured that the rest of all other factors identified as key to the Youth Guarantee's success is included in the implementation plans, this consistency is lacking with regard to the expected allocation of resources reported. In fact, 60 per cent of countries analysed have submitted proposed expenditures in their implementation plans below the recommended levels, which amounts to an estimated gap of 7.3 billion euros (PPP). This means these countries will have to make greater financial commitments if the desired objective of reducing youth unemployment is to be achieved. Interestingly, "adequacy of total funding" was also highlighted by the European Court of Auditors as one of the risks to the successful implementation of the Youth Guarantee (European Court of Auditors, 2015). ${ }^{15}$

Lastly, late programme implementation poses another threat to the Youth Guarantee's effectiveness. The pace of implementation should be closely monitored, since delays may create challenges, particularly for countries with high rates of long-term youth unemployment. Indeed, extended periods out of employment and the labour market have been proven to weaken the effectiveness of all activation policies (ILO, 2013).

${ }^{15}$ The other two risks identified by the European Court of Auditors included the meaning of a "good quality offer" and the monitoring and reporting by the European Commission of the scheme's results. 


\section{Bibliography}

Basu, A. K.; Chau, N. H.; Kanbur, R. 2009. "A theory of employment guarantees: Contestability, credibility and distributional concerns", in Journal of Public Economics, No. 93, pp. 482-497.

Bellmann, L.; Jackman, R. 1996a. “Aggregate Impact Analysis”, in Schmid, G.; O’Reilly, J.; Schömann, K. (eds.): International Handbook of Labour Market Policy and Evaluation, Edward Elgar, pp. 143-162.

—. 1996b. "The impact of labour market policy on wages, employment and labour market mismatch", in Schmid, G.; O’Reilly, J.; Schömann, K. (eds.): International Handbook of Labour Market Policy and Evaluation, Edward Elgar, pp. 725-746.

Besamusca J.; Stanescu I.; Vauhkonen J. 2012. The European youth guarantee: A reality check (Brussels: FEPS Young Academics Network).

Bussi, M.; Geyer, L. 2013. Youth Guarantees and recent developments on measures against youth unemployment: A mapping exercise (Brussels: European Trade Union Institute).

Blundell, B.; Costa Dias, M.; Meghir, C.; Van Reenen, J. 2004. "Evaluating the employment impact of a mandatory job search program", in Journal of the European Economic Association, No. 2, pp. 569-606.

Caliendo, M.; Künn, S. 2014. "Regional Effect Heterogeneity of Start-Up Subsidies for the Unemployed", in Regional Studies, Vol. 48, No. 6, 1108-1134.

Calmfors L.; Lang H. 1995. "Macroeconomic Effects of Active Labour Market Programmes in a Union Wage-Setting Model”, in The Economic Journal, Vol. 105, No. 430, pp. 601-619.

Calmfors, L.; Skedinger, P. 1995. "Does active labour market policy increase employment? Theoretical considerations and some empirical evidence from Sweden", in Seminar Papers, No. 590, (Stockholm: Institute for International Economic Studies, Stockholm University).

Card, D.; Kluve, J.; Weber A. 2010. “Active Labor Market Policy Evaluations: A Meta-Analysis”, in The Economic Journal, No. 1203 (November), pp. 452-477.

Clasen, J.; Clegg, D. 2006. "Beyond Activation: Reforming European Unemployment Protection Systems in Post-Industrial Labour Markets", in European Societies, Vol. 8, No. 4, pp. 527553.

Council. 2013a. Council Recommendation of 22 April 2013 on establishing a Youth Guarantee, 2013/C 120/01, April (Brussels).

De Giorgi, G. 2005. “The New Deal for Young People: Five Years On”, in Fiscal Studies, No. 26, pp. 371-383.

Dev, M. 1995. "India's (Maharashtra) employment guarantee scheme: Lessons from long experience", in von Braun, J. (ed.): Employment for Poverty Reduction and Food Security, pp. 108-143 (Washington DC: International Food Policy Research Institute).

Dolton, P.; O'Neill, D. 1996. "Unemployment Duration and the Restart Effect: Some Experimental Evidence”, in Economic Journal, No. 106, pp. 387-400. 
Drèze, J.; Sen, A. 1991. "Strategies of entitlement protection", in Hunger and Public Action, pp. 104121.

Escudero, V. 2015. Are active labour market policies effective in activating and integrating lowskilled individuals? An international comparison, Research Department Working Paper No. 3, (Geneva, International Labour Office).

European Commission. 2015. Piloting Youth Guarantee partnerships on the ground, DirectorateGeneral for Employment, Social Affairs \& Inclusion (Brussels).

- 2014. Preparatory Action on the Youth Guarantee - First Findings Report, Directorate-General for Employment, Social Affairs \& Inclusion (Brussels).

-. 2012a. Towards a job-rich recovery. Communication from the Commission to the European Parliament, the Council, the European Economic and Social Committee and the Committee of the Regions, 173 final (Brussels).

-. 2012b. Consolidated Version of the Treaty on the Functioning of the European Union, in Official Journal of the European Union, C 326, October (Brussels).

—. 2012c. Proposal for a Council Recommendation on Establishing a Youth Guarantee, 729 final, December (Brussels).

-. 2012d. Commission Staff Working Document accompanying the document Proposal for a Council Recommendation on Establishing a Youth Guarantee, 409 final, December (Brussels).

- 2010. Youth on the Move: An initiative to unleash the potential of young people to achieve smart, sustainable and inclusive growth in the European Union. Communication from the Commission to the European Parliament, the Council, the European Economic and Social Committee and the Committee of the Regions, 477 final, September (Brussels).

—. 2003. Green paper: Entrepreneurship in Europe, 27 final, January (Brussels).

European Council. 2013b. Conclusions of the European Council of 27/28 June, EUCO 104/2/13, June (Brussels).

European Court of Auditors. 2015. Young and unemployed in Europe: obstacles ahead for the EU's Youth Guarantee, Press Release, 24 March 2015 (Luxembourg).

Government of Spain. 2013a. Estrategia de Emprendimiento y Empleo Joven 2013/2016 (Strategy for Entrepreneurship and Youth Employment 2013-2016) (Madrid: Ministry for Employment and Social Security).

—. 2013b. Plan Nacional de Implantación de la Garantía Juvenil en España (Spanish National Youth Guarantee Implementation Plan) (Madrid: Ministry for Employment and Social Security).

Graversen, K. B.; van Ours, J. C. 2008. "How to Help Unemployed Find Jobs Quickly: Experimental Evidence from a Mandatory Activation Program", in Journal of Public Economics, No. 92, pp. 2020-2035.

Hardoy, I.; Røed, K.; Torp, H.; Zhang, T. 2006. "Virker ungdomsgarantien?” (Does the youth guarantee work?), in Institute for Social Research, Søkelys på arbeidsmarkedet 23. 
International Labour Organization (ILO). 2014. Spain: Growth with jobs, Studies on Growth with Equity) (Geneva: Research Department).

—. 2013. Youth guarantees: A response to the youth employment crisis? Employment Policy Brief (Geneva: Employment Policy Department).

—. 2012. Eurozone Job Crisis: Trends and Policy responses. Studies on Growth with Equity (Geneva: International Institute for Labour Studies).

Layard R.; Nickell S.; Jackman R. 2009. Unemployment: Macroeconomic Performance and the Labour Market (Oxford: Oxford University Press).

Layard R.; Nickell S. 1986. "Unemployment in Britain”, in Economica, New Series, Vol. 53, No. 210, Supplement: Unemployment (1986), pp. S121-S169.

Liu, K.; Salvanes, K.G.; Sørensen, E. 2012. Good skills in bad times: Cyclical skill mismatch and the long-term effects of graduating in a recession, IZA Discussion Paper, No. 6820 (Bonn: Institute for the Study of Labor).

Mascherini, M. 2012. Youth guarantee: Experiences from Finland and Sweden (Dublin: European Foundation for the Improvement of Living and Working Conditions).

Micklewright, J.; Nagy, G. 2010. "The Effect of Monitoring Unemployment Insurance recipients on Unemployment Duration: Evidence from a Field experiment", in Labour Economics, No. 17, pp. 180-187.

Organisation for Economic Co-operation and Development (OECD). 1993. "Active labour market policies: Assessing macroeconomic and microeconomic effects", in Employment Outlook, Chapter 2, pp. 39-80 (Paris).

Pissarides, C. 1990. Equilibrium Unemployment Theory, Blackwell.

Ravallion, M. 1991. "Reaching the rural poor through public employment", in The World Bank Research Observer. Vol. 6, No. 2 (July 1991), pp. 153-175.

Schmid, G. 1996. "New Public Management of Further Training”, in Schmid, G.; O'Reilly, J.; Schömann, K. (eds.): International Handbook of Labour Market Policy and Evaluation, Edward Elgar, pp. 725-746.

Schmid, G.; Speckesser, S.; Hilbert, C. 2001. "Does active labour market policy matter? An aggregate impact analysis for Germany", in de Koning, J.; Mosley, H. (eds.): Labour Market Policy and Unemployment: impact and process evaluations in selected European countries, Edward Elgar, pp. 78-114.

Van den Berg, G.J.; Bergemann, A.H.; Caliendo, M. 2009. "The Effect of Active Labor Market Programs on Not-Yet Treated Unemployed Individuals", in Journal of the European Economic Association, No. 7, pp. 606-616.

Van den Berg, G.J.; van der Klaauw, B. 2006. "Counselling and Monitoring of Unemployed Workers: Theory and Evidence from a Controlled Social Experiment", in International Economic Review, No. 47, pp. 895-936. 